\title{
Wacana Iklan Kartu Kredit versi Lucky Reward
}

\author{
Deni Albar \\ Program Studi Desain Komunikasi Visual, Universitas Komputer Indonesia
}

\begin{abstract}
Abstrak. Sebagai salah satu kajian wacana, iklan adalah sebuah model komunikasi yang menarik, karena keunikan dalam iklan maka dapat dibedakan bentuk komunikasi wacana tulis atau non-tulis yang lain. Pesan dalam iklan memiliki dua tingkatan makna, yaitu makna eksplisit dan makna yang dikemukakan secara implisit di balik tampilan iklan. Iklan kartu kredit sebagai sebuah produk budaya populer pada saat sekarang ini menjadi sebuah fenomena tersendiri di masyarakat. Kartu kredit merupakan alat bantu pembayaran yang sudah biasa di sebagian masyarakat kita. Salah satu perusahaan yang mengeluarkan produk kartu kredit adalah bank CIMB Niaga.
\end{abstract}

Dalam iklan program "Lucky Reward" kartu kredit CIMB Niaga terdapat kodekode yang memiliki nilai-nilai, sikap, dan keyakinan tertentu. Wacana ini difokuskan pada kajian tentang makna yang terkandung dalam tatanan objekobjek yang muncul dalam iklan program "Lucky Reward". Wacana ini diharapkan memberikan kontribusi penting terhadap kajian analisis wacana sehingga dapat dijadikan rujukan untuk kajian selanjutnya. Objek-objek tekstual yang muncul pada iklan merupakan kalimat yang memiliki makna terselubung. Pelesapan atau elipsis digunakan untuk memadatkan kata atau mempersingkat kata supaya susunan kalimat menjadi singkat, padat, dan menarik. Berdasarkan analisis sociocultural practise dalam Lucky Reward, terdapat tiga level yakni level situasional, level institusional dan level sosial.

Kata kunci: Wacana, Iklan, Kartu Kredit.

\section{PENDAHULUAN}

Sebagai salah satu kajian wacana, iklan adalah sebuah model komunikasi yang menarik, karena keunikan dalam iklan maka dapat dibedekan bentuk komunikasi wacana tulis atau non-tulis yang lain. Dalam sebuah iklan, dikomunikasikan citra secara maksimun guna mencapai target sasaran dan terjalin sebuah komunikasi yang diharapkan. Iklan sebagai sebuah teks adalah suatu sistem terorganisir yang mana didalamnya terdapat kode-kode bernilai dan bermakna tertentu. Pesan dalam iklan memiliki dua tingkatan makna, yaitu makna yang dikemukakan secara eksplisit di permukaan dan makna yang dikemukakan secara implisit di balik permukaan tampilan iklan (Noviani, 2002, 79) dalam Sumarlam $(2004,1)$. 
Kartu kredit sebagai sebuah produk budaya populer pada saat sekarang ini menjadi sebuah fenomena tersendiri di masyarakat. Kartu kredit merupakan alat bantu pembayaran yang sudah biasa di sebagian masyarakat kita. Kartu kredit bahkan memberikan banyak peluang tambahan bagi konsumen pengguna untuk mendapatkan kemudahan baik dalam bertransaksi maupun sistem pembayaran yang bisa dicicil. Penggunaan kartu kredit telah berkembang sedemikian pesat dalam memenuhi tuntutan dan gaya hidup masyarakat modern. Posisi kartu kredit di masyarakat memiliki nilai-nilai tertentu yang bisa dilihat tidak hanya dari sisi nilai nominal uang. Karena pengguna kartu kredit di Indonesia memiliki ciri-ciri dan selera yang berlainan, dan semakin banyaknya pesaing yang bermunculan, maka agar suatu perusahaan bisa tetap eksis dan bisa memenangkan persaingan maka perusahaan tersebut harus bisa melakukan eksplorasi terhadap daya tarik kartu kredit. Untuk mempertahankan eksistensinya dalam dunia bisnis, perusahaan melakukan suatu program dan iklan.

Menurut A.F. Elly Erawaty dan J.S Badudu dalam buku DR.Johannes Ibrahim, SH., MH (2004, 10) menjelaskan pengertian kartu kredit yakni “Kartu yang dikeluarkan oleh Bank atau lembaga lain yang diterbitkan dengan tujuan untuk mendapatkan uang, barang atau jasa secara kredit." Sedangkan menurut Prof. Dr. Abdullah al-Mushlih (2009) secara bahasa, Kata 'kartu' digunakan untuk potongan kertas kecil atau dari bahan lain, diatasnya ditulis penjelasan yang berkaitan dengan potongan kertas itu. sementara kata 'kredit' secara bahasa artinya adalah kondisi aman dan saling percaya. Atas dasar kepercayaan itu, maka kartu kredit dapat diartikan sebagai kartu yang dikeluarkan oleh pihak bank dan sejenisnya yang dapat digunakan oleh pembawanya untuk membeli segala keperluan dan barang-barang serta pelayanan tertentu secara hutang.

Kartu kredit merupakan alat bantu pembayaran yang sudah biasa di sebagian masyarakat kita. Kartu kredit bahkan memberikan banyak peluang tambahan bagi konsumen pengguna untuk mendapatkan kemudahan baik dalam bertransaksi 
maupun sistem pembayaran yang bisa dicicil. Penggunaan kartu kredit telah berkembang sedemikian pesat dalam memenuhi tuntutan dan gaya hidup masyarakat modern. Posisi kartu kredit di masyarakat memiliki nilai-nilai tertentu yang bisa dilihat tidak hanya dari sisi nilai nominal uang. Pihak bank memiliki peran yang besar dalam pendistribusian kartu kredit ke masyarakat. Bank sangat gencar mempromosikan kartu kredit. Mulai dari diskon, hadiah, promosi kartu gratis dan bahkan menjadikan kartu kredit itu sebagai bagian dari gaya hidup. Orang yang memiliki banyak kartu kredit akan dianggap sebagai seorang yang bonafit. Bahkan bagi para eksekutif muda, belum gaul kalau belum memiliki kartu kredit.

Salah satu perusahaan yang mengeluarkan produk kartu kredit adalah bank CIMB Niaga. CIMB Niaga sudah dikenal sebagian besar masyarakat Indonesia dan merupakan salah satu bank besar yang sudah kokoh keberadaannya dalam dunia perbankan Indonesia. Salah satu program dan iklan yang dikeluarkan oleh pihak bank CIMB Niaga adalah Program Point Kartu Kredit "Lucky Reward". Dalam iklan program "Lucky Reward” kartu kredit CIMB Niaga tentunya juga terdapat kode-kode yang memiliki nilai-nilai, sikap, dan keyakinan tertentu. Kode dalam iklan kartu kredit CIMB Niaga menjadi suatu wacana yang menarik untuk dikaji lebih dalam. Wacana yang terdapat dalam iklan "Lucky Reward" perlu dikaji untuk mendapatkan makna dan hubungan sosial yang terjadi. Dalam iklan program "Lucky Reward” kartu kredit CIMB Niaga tidak hanya tersaji gambar atau objek tanpa tujuan. Objek-objek yang muncul dalam iklan tersebut memiliki tujuan-tujuan tertentu guna mempengaruhi khalayak yang menilainya. Dengan demikian, wacana ini akan mengungkapkan makna yang terdapat dalam iklan program “Lucky Reward” kartu kredit CIMB Niaga. 


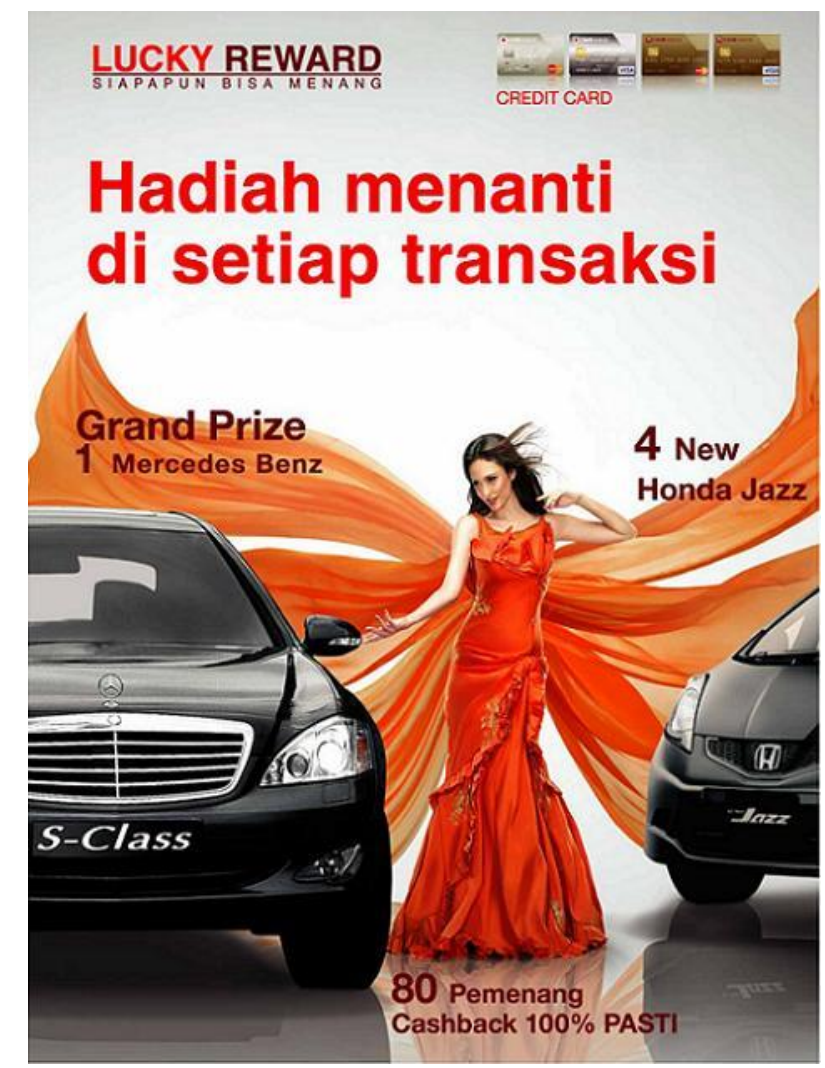

Gambar 1.1 Iklan Cetak Lucky Reward Kartu Kredit CIMB Niaga

\section{METODE \& PEMBAHASAN}

Iklan menurut Graeme Burton adalah relasi komunikasi yang merupakan titik persinggungan antara kepentingan komersial dan khalayak sebagai konsumen barang dan jasa, sedangkan iklan menurut Acep Iwan Saidi adalah sebuah produk desain yang menandai berpindahnya barang dan jasa ke dalam ranah bahasa yang mensubversi khalayak dengan seperangkat nilai sosial, ekonomi, ideologi, dan budaya yang memanfaatkan (representasi) sekaligus mengkonstruksi realitas (Saidi, 2009). Pada dasarnya iklan merupakan suatu bentuk komunikasi komersil maupun non-komersil terhadap khalayak yang di desain untuk mempromosikan suatu produk atau jasa, atau pesan dari sebuah institusi maupun organisasi. Bukti keberadaan iklan dapat dilihat dari budaya masyarakat sejak ribuan tahun lalu, arkeolog membuktikan sudah ada papan nama sebuah toko sebagai bagian dari iklan di Babylonia sekitar tahun 3000 sebelum masehi. Namun iklan sebagai sebuah industri besar baru dikenal pada abad ke-20. 
Para pakar mempercayai bahwa iklan memiliki pengaruh penting dalam bidang ekonomi dan sosial. Namun, sebagian iklan juga dikritisi sebagai penyebab munculnya budaya materialistis dan konsumtif atau bahaya dari streotype yang buruk. Baik di Indonesia maupun banyak negara lain, iklan di ikat oleh berbagai peraturan untuk mencegah atau membatasi dampak negatif yang dikhawatirkan. Iklan dapat dibagikan menjadi beberapa jenis, menurut Brett Robbs (2009), iklan diranah publik terbagi menjadi institutional, image, informational dan cooperative. Iklan institusional bertujuan mencari kesan dan impresi dari suatu bisnis atau institusi tanpa berusaha menjual sebuah produk tertentu. Jenis iklan ini dirancang untuk membangun prestise dan respek dari publik. Jenis iklan ini menawarkan keunikan suatu produk yang diharapkan dipilih oleh konsumen. Biasanya jenis iklan ini merupakan bagian dari rangkaian pencitraan merek. Iklan Informasi bertujuan mempromosikan sebuah ide atau mempengaruhi dan merubah suatu kebiasaan tertentu, biasa di tujukan untuk kegiatan sosial. Iklan Kerja-sama merupakan perjanjian antara manufaktur dan ritel dimana pihak manufaktur memberikan sejumlah kredit pada pihak ritel untuk mengiklankan produknya. Untuk menjangkau para konsumen, iklan menggunakan berbagai media dalam penyampaiannya. Beberapa media populer tentunya juga memerlukan biaya yang besar, seperti media televisi, koran, surat, radio, majalah, internet, iklan luar ruang dan berbagai jenis media lain termasuk iklan di kendaraan, bonus dan berbagai hal lain.

Salah satu metode untuk mengungkap iklan adalah dengan metode diskursus. Diskursus hadir diberbagai bidang ilmu, penggunaan kata diskursus atau wacana digunakan banyak kalangan baik dari studi bahasa, psikologi, , sastra, sosiologi, komunikasi, politik dan lain sebagainya. Diskursus atau wacana menurut J.S. Badudu (2000) dalam Eriyanto (2001, 2) "Rentetan kalimat yang berkaitan, yang menghubungkan proposisi yang satu dengan proposisi yang lainnya, membentuk satu kesatuan, sehingga terbentuklah makna yang serasi diantara kalimat-kalimat itu". Wacana menurut Foucault (1972) dalam Eriyanto $(2001,2)$ yakni "kadang kala sebagai bidang dari sebuah pernyataan (statement), kadang kala sebagai 
sebuah individualisasi kelmpok pernyataan, dan kadang kala sebagai praktik regulatif yang dilihat dari sejumlah pernyataan". Diskursus merupakan seperangkat aransemen/gubahan teks yang mengatur dan mengkordinasikan tindakan, posisi dan identitas orang yang terlibat di dalamnya (Saidi, 2009). Dalam analisis diskursus, suatu media atau teks tidak dibaca secara formal yang memperhatikan unit kata atau frase, melainkan pada hubungan yang lebih besar dari sebuah kalimat. Wacana merupakan suatu upaya pengungkapan maksud tersembunyi dari sang subjek yang mengemukakan suatu pernyataan.

\subsection{Skema Iklan Cetak "Lucky Reward"}

Berikut penjabaran skema program "Lucky Reward” kartu kredit CIMB Niaga.

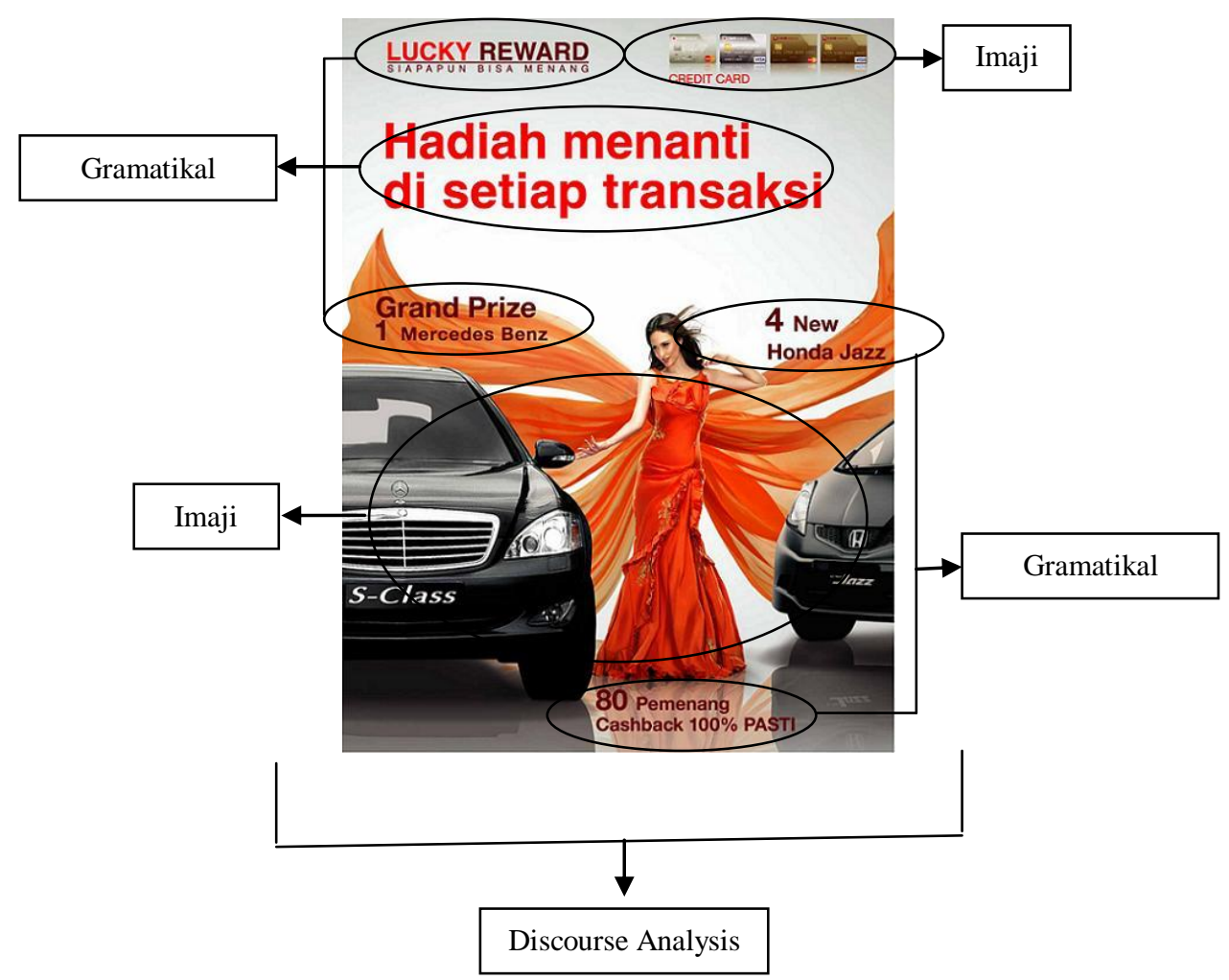

Program Studi Desain Komunikasi Visual, Universitas Komputer Indonesia 


\subsection{Tekstual}

Relasi tanda atau hubungan makna antara unsur-unsur didalam objek kajian dan unsur-unsur lain untuk menginterpretasikan suatu kajian teks, hubungan antara makna-makna yang ada didalamnya. Moeliono dalam Sumarlam dkk (2005:173) menyatakan keserasian antara unsur yang satu dengan unsur yang lain dalam wacana menciptakan pengertian yang apik. Relasi dalam iklan ini ditandai dengan relasi gramatikal. Analisis gramatikal merupakan analisis dari segi bentuk atau struktur wacana. Analisis wacana iklan program "Lucky Reward" kartu kredit CIMB Niaga terdiri dari aspek kohesi gramatikal yakni pelesapan (elipsis). Pelesapan merupakan salah satu jenis gramatikal yang merupakan penghilangan atau pelesapan satuan lingual tertentu. Pada wacana iklan "Lucky Reward" kartu kredit CIMB Niaga ditemukan penghilangan kata sehingga menimbulkan efek pelesapan dua kata. Pelesapan ini digunakan untuk memadatkan kata atau mempersingkat kata supaya susunan kalimat menjadi singkat, padat, dan menarik.

\section{Hadiah menanti di setiap transaksi}

Kata transaksi merupakan kata yang tidak jelas dimana transaksi dapat berarti luas dan sangat memungkinkan memiliki ketentuan-ketentuan tertentu yang berlaku didalamnya. Seharusnya;

$\times \quad$ "Hadiah menanti disetiap transaksi".

$\checkmark \quad$ "Hadiah menanti disetiap transaksi dengan CIMB Niaga".

\section{LUCKY REWARD}

× "Lucky reward, siapapun bisa menang".

$\checkmark \quad$ "Lucky reward, siapapun pengguna CIMB Niaga bisa menang". 
× “80 Pemenang, Cashback 100\% PASTI".

$\checkmark \quad$ "80 Pemenang, Cashback 100\% transaksi terakhir CIMB Niaga PASTI".

Dalam analisis diatas, terdapat penghilangan kata menjadi lebih singkat. Dengan adanya pelesapan tersebut, diharapkan pembaca termotivasi untuk lebih kreatif menemukan unsur-unsur yang tidak diungkapkan dalam kalimat. Tentunya apabila dilihat lebih mendalam, ada perintah khusus dari pemberi informasi (subjek) dimana pemegang kartu kredit (objek) agar lebih konsumtif dalam menggunakan kartu kredit CIMB Niaga, dan tentunya ada rayuan kepada non pemegang kartu kredit CIMB Niaga untuk menjadi pemegang kartu kredit CIMB. Sedangkan imaji mobil dan perempuan digunakan untuk membantu, mempertegas, merayu atau membujuk audiens dalam mengarahkan pemikiran logis pesan menjadi 'kabur' dan menjadi sebuah rayuan fantasi.

\subsection{Kontekstual}

Mengacu pada analisis Sociocultural Practice dari Norman Fairclough dalam Eriyanto (2001), maka analisis didasarkan pada asumsi bahwa konteks sosial yang ada diluar media mempengaruhi bagaimana wacana yang muncul dalam media. Sociocultural Practise menentukan bagaimana teks diproduksi dan dipahami. Sociocultural Practise menggambarkan bagaimana kekuatan kekuatan yang ada dalam masyarakat memaknai dan menyebarkan ideologi yang dominan kepada masyarakat. Fairclough membuat tiga level analisis pada Sociocultural Practise yakni situasional, institusional, dan sosial.

\section{Tingkat Situasional}

Dalam analisis situasional, perlu diperhatikan aspek ketika kapan teks diproduksi. Teks merupakan hasil dari suatu keadaan dan suasana tertentu. Dalam iklan "Lucky Reward” kartu kredit CIMB Niaga, situasi yang ada pada saat iklan dibuat adalah keadaan dimana khalayak ramai sudah terbiasa dengan gaya hidup konsumtif, dimana penggunaan kartu kredit menjadi hal biasa di masyarakat. 
Kartu kredit yang sudah lumrah dimiliki masyarakat, membuat si pemberi pesan (subjek) CIMB Niaga harus melihat gaya konsumtif dari pengguna kartu kredit di masyarakat. Gaya hidup konsumtif masyarakat saat ini dimanfaatkan pihak pemberi pesan (CIMB Niaga) untuk membuat program "Lucky Reward" dengan cara transaksi belanja sesering mungkin guna menghasilkan point belanja sebanyak-banyaknya. Disatu sisi, pihak CIMB Niaga jelas diuntungkan dengan kredit yang besar dari para nasabahnya, sedangkan para nasabah kartu kredit secara tidak sadar telah dikuasai untuk melakukan transaksi belanja.

\section{Tingkat Institusional}

Pada tingkatan institusional, bagaimana pengaruh institusi organisasi dalam praktik produksi wacana. Faktor penting dalam institusi adalah yang berhubungan dengan ekonomi media, tentunya faktor yang pertama adalah nasabah. Nasabahlah yang menentukan kelangsungan hidup institusi. Dengan demikian, iklan harus sedemikian rupa menarik minat nasabah untuk bertransaksi dengan kartu kredit CIMB Niaga. Untuk itu, iming-iming hadiah mewah menjadi cara dalam praktek penguasaan pola pikir konsumtif objek (khalayak).

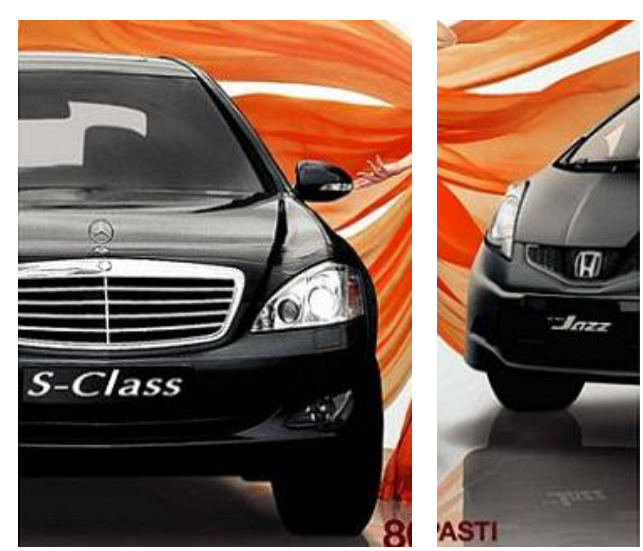

Gambar 2.1. Hadiah Mobil Mewah

Faktor kedua berkaitan dengan jumlah nasabah kartu kredit CIMB Niaga, semakin banyak yang menjadi nasabah (objek), semakin kuat pula institusi (subjek). Dengan demikian, subjek dituntut harus menciptakan "Rayuan yang baik" yang 
disukai oleh banyak orang termasuk pra-nasabah (objek). Tema yang muncul dalam iklan dipilih, disesuaikan dengan keinginan masyarakat. Munculnya dramatisasi isu dengan tema 'SIAPAPUN BISA MENANG' mencoba untuk menguasai pola pikir pra-nasabah untuk bisa mendapatkan hadiah sehingga menarik minat untuk menjadi nasabah. Adanya pelesapan (elipsis) dalam tekstual media tanpa memperjelas rangkaian kata seolah-olah promosi iklan ditujukan untuk semua orang.

Faktor ketiga adalah persaingan antar media, pada dasarnya, pemberi kredit seperti bank memperebutkan nasabah, sehingga diperlukan unique selling point dalam membedakan dengan iklan media serupa. Selain faktor yang berkaitan dengan ekonomi, hal yang berkenaan dengan kepemilikan media (subjek), siapa yang menjadi pemilik media dapat mempengaruhi keberlangsungan teks, faktor lainnya adalah politik yang berlangsung, iklan sebisa mungkin tidak bertolak belakang dengan kebijakan yang berkaitan dengan politik tertentu guna keberlangsungan institusi. Dalam hal ini, CIMB Niaga sebagai subjek tidak boleh membuat iklan yang mengandung unsur-unsur provokasi pada pemerintahan atau pelaku politik beserta regulasi yang berlaku.

\section{Tingkat Sosial}

Fairclough dalam Eriyanto $(2001,325)$ menegaskan bahwa "wacana yang muncul dalam media ditentukan oleh perubahan masyarakat”. Dalam tingkatan sosial, budaya masyarakat turut menentukan wacana media. Masyarakat Indonesia yang menganut ideologi patriarkal, dimana kaum perempuan menjadi kelas dua dibawah laki-laki mempengaruhi unsur-unsur yang muncul pada media iklan “Lucky Reward” kartu kredit CIMB Niaga. 


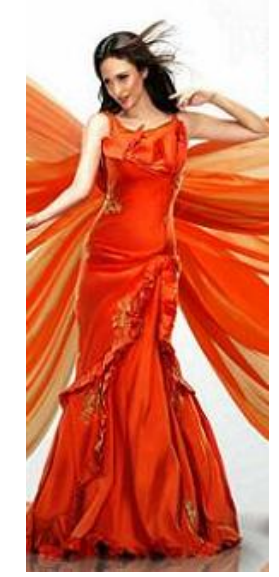

Gambar 2.2. Sosok Perempuan Cantik

Sosok perempuan yang menjadi komoditi dalam ideologi patriarkal muncul dalam promosi iklan "Lucky Reward” kartu kredit CIMB Niaga. Selain untuk menarik minat para kaum pria dan sebagai objek pasif hasrat dan kendali para kaum pria, tak jarang sosok perempuan yang bergaya genit dan menggoda muncul di majalah-majalah perempuan. Tony Thwaites $(2002,229)$.

Imaji seorang perempuan yang didominasi adegan genit dan rayuan sudah tertanam kuat di masyarakat. Kuatnya imaji perempuan yang kemudian muncul pada iklan "Lucky Reward" kartu kredit CIMB Niaga sebenarnya adalah pengulangan dari berbagai media yang sudah ada. Institusi media melakukan suatu pengkodean pada keadaan sosial yang terjadi di masyarakat, dengan anggapan seolah yang menjadi objek menganut nilai dan pemaknaan yang sama. Dengan demikian malalui level sosial yang ada, subjek mampu menunjukan satu pola kecenderungan dimasyarakat (komunitas imajiner). Adanya komunitas imajiner ini membuat perasaan yang saling terhubung terlepas dari adanya jarak dan perbedaan. 


\section{KESIMPULAN}

Setelah mengkaji iklan promosi "Lucky Reward" kartu kredit CIMB Niaga, maka dapat disimpulkan;

Objek-objek tekstual yang muncul pada iklan merupakan kalimat yang memiliki makna terselubung. Pelesapan atau elipsis digunakan untuk memadatkan kata atau mempersingkat kata supaya susunan kalimat menjadi singkat, padat, dan menarik. Dengan adanya pelesapan tersebut, diharapkan pembaca termotivasi untuk lebih kreatif menemukan unsur-unsur yang tidak diungkapkan dalam kalimat. Berdasarkan analisis sociocultural practise, terdapat tiga level yakni level situasional, level institusional dan level sosial. Pada level situasional, perlu diperhatikan aspek ketika kapan teks diproduksi. Teks merupakan hasil dari suatu keadaan dan suasana tertentu. Sedangkan pada level institusional, bagaimana pengaruh institusi organisasi dalam praktik produksi wacana. Beberapa hal yang mempengaruhi diantaranya adalah nasabah dan calon nasabah, kepemilikan media, politik dan regulasi. Pada level sosial, wacana yang muncul dalam media ditentukan oleh pola sosial masyarakat. Ideologi patriarkal sering kali menjadikan objek dalam media sebuah pengulangan dimana sosok wanita sebagai komoditi selalu muncul.

\section{DAFTAR PUSTAKA}

Abdullah. Defenisi Kartu Kredit. Dikutip dari http://www.alsofwah.or.id/?pilih= indexanalisa\&id=295\&section=an020 (Diakses 21/12/2009).

Eriyanto. 2001. Analisis Wacana:Pengantar Analisis Teks Media. Yogyakarta: LKIS Pelangi Aksara.

Ibrahim, Johannes. 2004. Kartu Kredit. Jakarta: Aditama.

Robbs, Brett. 2008. Advertising [DVD]. Redmond, WA Microsoft ${ }^{\circledR}$ Encarta ${ }^{\circledR}$ 2009.

Saidi, Acep Iwan. 2009. Di Balik Iklan. Bandung: Institut Teknologi Bandung 
VISUALITA, Vol.2 No.1 - Februari 2010 : 29-41 ISSN : 2301-5144 (online)

http://visualita.unikom.ac.id/

Saidi, Acep Iwan. 2009. Discourse Analysis. Bandung: Institut Teknologi Bandung

Sumarlam, et.al. 2004. Analisis Wacana: Iklan, Lagu, Puisi, Cerpen, Novel, Drama. Bandung: Pakar Raya.

Twhaites, Tony, et.al. 2009. Intoducing Cultural And media Studies: Sebuah Pendekatan Semiotik. Yogyakarta: Jalasutra. 